\title{
GRK2 wt Allele
}

National Cancer Institute

\section{Source}

National Cancer Institute. GRK2 wt Allele. NCI Thesaurus. Code C51179.

Human GRK2 wild-type allele is located in the vicinity of 11 q13.2 and is approximately 20

$\mathrm{kb}$ in length. This allele, which encodes beta-adrenergic receptor kinase 1 protein, is involved in the phosphorylation of beta-adrenergic and related G protein-coupled receptors. 